\title{
Faktor-faktor yang Memengaruhi Perilaku Konsumen dalam Bertransaksi di Media Sosial
}

\author{
Irfan Aulia Syaiful ${ }^{1}$, Anggit Verdaningrum Kumala Sari ${ }^{2}$ \\ Universitas Mercubuana, Jakarta
}

\begin{abstract}
This research is in the area of consumer behavior. Many of these factors can be confusing for company to map consumer behavior into its target market. Therefore, the purpose of this study was to determine the factors influencing consumer behavior transactions in social media. This research using qualitative method. Our subjects involved 5 consumers who make transactions in social media. Techniques of data collection is done by observation and structured interviews, while the data collection tool used as interview guides and recorder. Based on the results it was found that four of these factors influence consumer behavior in social media, in the cultural factors such as between consumers and sellers adjust to each other in the language selection, social factors such as testimonials, offer from a friend, how the seller described the product, personal factors such as convenience at shopping (even when in the bathroom), while psychological factors such as discounts, product packaging and delivery speed.
\end{abstract}

Keywords: customer behavior; social media

\begin{abstract}
Abstrak: Banyak faktor yang membingungkan perusahaan dalam memetakan perilaku konsumen yang menjadi targetnya. Penelitian ini berupaya menggambarkan faktor-faktor yang memengaruhi perilaku transaksi konsumen di media sosial. Metode yang digunakan adalah kualitatif yang melibatkan sebanyak 5 orang dengan karakter telah sering melakukan transaksi belanja lewat media sosial. Teknik pengambilan data dilakukan dengan observasi dan wawancara terstruktur. Hasil penelitian menunjukkan, ada tiga faktor yang memengaruhi perilaku konsumen di media sosial. Pertama, faktor budaya seperti antara kesesuaian bahasa antara konsumen dan penjual, faktor sosial seperti testimonial, tawaran dari teman, cara penjual mendeskripsikan produk. Kedua, faktor pribadi seperti kemudahan berbelanja. Ketiga, faktor psikologis seperti diskon, waktu pengiriman, dan pengemasan produk.
\end{abstract}

Kata kunci: perilaku konsumen; sosial media

Media sosial telah memberikan peluang baru bagi konsumen terlibat dalam interaksi sosial di internet (Hajli \& Nick, 2013). Menurut Zarella (2010), pada dasarnya media sosial

Korespondensi mengenai isi artikel ini dapat dilakukan melalui email: ${ }^{1}$ tanyairfanaulia@gmail. com , 2anggitverda@gmail.com 


\section{Irfan Aulia Syaiful, Anggit Verdaningrum Kumala Sari}

merupakan perkembangan mutakhir dari teknologi-teknologi web baru berbasis internet, yang memudahkan semua orang untuk dapat berkomunikasi, berpartisipasi, saling berbagi, dan membentuk sebuah jaringan secara daring.

Hal ini memudahkan pengguna untuk dapat menyebarluaskan konten mereka sendiri. Kiriman melalui blog, tweet, atau video YouTube dapat direproduksi dan dilihat langsung oleh jutaan orang secara gratis. Selain itu, Habibi, Lorache, \& Richard (2016) mengungkapkan media sosial memberikan kekuatan untuk pelanggan dalam berbagi informasi baik tips dan trik untuk menggunakan produk dalam berbagai merek. Dengan begitu media sosial merupakan wadah masyarakat untuk berinteraksi sosial secara langsung dan interaktif mengenai produk tertentu layaknya media tradisional seperti tv dan radio.

Mukhaini, Ismael, \& Al-Dhuhli (2014) mengungkapkan media sosial telah memberikan banyak kesempatan kepada konsumen dalam beradaptasi mengenai aspek yang berbeda dalam keseharian. Media sosial seperti facebook, twitter, dan instagram telah memainkan peran penting dalam memperluas pembelian daring konsumen. Berdasarkan beberapa pendapat di atas, diketahui bahwa media sosial memberikan kemudahan berbagi informasi antara konsumen yang satu dengan konsumen yang lain yang juga dapat membuat konsumen lain melakukan transaksi. Miller (2010) memperlihatkan bahwa 70\% dari konsumen mengunjungi media sosial untuk mendapatkan informasi yang berguna, $49 \%$ dari mereka membuat keputusan untuk membeli produk tertentu, dan $60 \%$ konsumen lebih memilih untuk berbagi informasi tentang produk dengan orang lain secara online (dalam Mukhaini, Ismael, \& Al-Dhuhli, 2014). Menurut penelitian Mukhaini, Ismael, \& AlDhuhli (2014), instagram telah membuat perubahan signifikan dalam keputusan pembelian konsumen terhadap produk tertentu. Dalam penelitian tersebut sebagian besar konsumen dipengaruhi oleh faktor informasi dan desain yang membantu mereka untuk mengambil keputusan terbaik dalam memilih produk yang paling sesuai di media sosial (instagram).

Dalam pembelian sebuah produk, Budiman, Choor, Razdan, \& Sohoni (2012) mengungkapkan 90\% masyarakat Indonesia sadar dengan produk yang akan mereka beli dan gunakan. Di dalam penelitian itu juga disebutkan $85 \%$ konsumen mencari tahu produknya melalui $\mathrm{TV}, 53 \%$ rekomendasi dari keluarga dan teman, koran $20 \%$, sales promosi $17 \%$, internet $5 \%$, roadshow $5 \%$, pamflet di bus dan sebagainya $1 \%$. Selain itu, Madni (2014) melakukan penelitian kepada 1000 subjek dengan rentang usia antara 18 sampai 50 tahun dan didapatkan hasil $47 \%$ konsumen membeli barang secara online adalah anak muda 


\section{Faktor-faktor yang Memengaruhi Perilaku Konsumen ....}

dengan memegang status sebagai sarjana dengan usia antara 25-29 tahun. Konsumen yang membeli online biasanya perempuan muda, bekerja di perusahaan, dengan gaji bulanan di atas 30. 000 rupee Pakistan (setara dengan kurang lebih 5, 8 juta rupiah) dan sebagian besar minimal memiliki satu akun jejaring sosial media. Sebelum membeli produk di internet, $53 \%$ konsumen biasanya mencari informasi melalui forum di internet, akun media sosial, website perusahaan, dan peer review. Selain itu, salah satu alasan yang paling sering disebutkan konsumen dalam memilih transaksi online adalah kenyamanan $(47 \%)$, dan kemudahan produk dikirim ke rumah (43\%). Berdasarkan penelitian di atas diketahui bahwa konsumen melakukan survey produk untuk mengetahui jenis, bentuk, manfaat, dan harga sebelum memilih membeli produk dalam media sosial serta diketahui bahwa konsumen perempuan muda (khususnya usia 20-30 tahun) lebih banyak dibandingkan konsumen laki-laki dalam melakukan pembelian secara online.

Ioanas \& Stoice (2014) mengungkapkan sebagian besar konsumen yang membeli adalah pemuda berusia 25-29 tahun. Pada penelitian ini didapati $47 \%$ subjek membeli atau berbelanja secara online berusia 25-29 tahun, mayoritas pembeli berusia muda ini adalah perempuan. Aktivitas yang kelompok ini lakukan sebelum melakukan pembelian adalah membaca ulasan dan komentar dari produk yang diinginkan terlebih dahulu seperti dari website perusahaan, dari facebook, ataupun yang berupa blog. Pada penelitian ini didapati $42 \%$ konsumen melakukan pembelian secara online karena nyaman membeli secara online dan 39\% konsumen merasa pengiriman produk online cepat sampai di rumah.

Dalam melakukan pembelian, ada faktor-faktor yang memengaruhi pembelian. Petra (tanpa tahun) menyatakan faktor sosial seperti kondisi sosial ekonomi dan pendapatan dapat memengaruhi perilaku transaksi konsumen. Faktor lainnya adalah faktor dari produsen seperti diskon. Yakup, Mucahit, \& Reyhan (2011) menyebutkan dua area faktor utama dalam perilaku transaksi konsumen (perilaku membeli barang). Area pertama adalah kualitas produk, pelayanan prima dari produsen dan distributor, budaya lingkungan konsumen, tradisi, dan keyakinan konsumen terhadap produk. Area pertama ini mempunyai pengaruh sebesar 86,8 persen. Area kedua adalah lingkungan, teman, dan kelompok sosial sebesar 48,6 persen. Dari penelitian ini tampak bahwa area pertama memiliki pengaruh yang lebih besar dalam perilaku transaksi konsumen.

Yakub, Mucahit, \& Reyhan (2011) mengungkapkan konsumen terbesar yang melakukan pembelanjaan adalah orang tua laki-laki dengan status sebagai ayah sebesar 25 , $8 \%$. Ibu sebesar $13,1 \%$, anak sebesar 2,6\%, kedua orang tua $23,7 \%$. Dalam membeli barang, 


\section{Irfan Aulia Syaiful, Anggit Verdaningrum Kumala Sari}

kualitas dan pelayanan, budaya, keyakinan pelanggan dan tradisi memberikan pengaruh yang besar yaitu 86,8\% sedangkan faktor lingkungan, teman, dan kelompok sosial memberikan pengaruh sebesar $48,6 \%$ saja. Dalam hal ini pengaruh budaya memiliki dampak yang besar.

Menurut Kotler \& Keller (2008) studi perilaku konsumen adalah studi mengenai cara individu, kelompok, dan organisasi memilih, membeli, menggunakan, dan menempatkan barang, jasa, ide, atau pengalaman untuk memuaskan keinginan dan kebutuhan mereka. Kotler \& Keller (2008) menjelaskan ada beberapa faktor yang memengaruhi perilaku konsumen, yaitu: faktor budaya, sosial, personal, dan psikologis. Faktor kebudayaan sangat berpengaruh terhadap perilaku konsumen, diantaranya: pertama, budaya yang meliputi: keluarga, sekolah, pemuka agama, dan teman bermain. Kedua, sub-budaya, meliputi: kebangsaan, agama, kelompok ras, dan daerah geografis. Ketiga, kelas sosial.

Faktor sosial juga memengaruhi perilaku konsumen, diantaranya: kelompok acuan, keluarga, dan status sosial. Selain faktor budaya dan sosial, faktor personal juga berpengaruh terhadap perilaku konsumen, diantaranya: usia, pekerjaan dan lingkungan ekonomi, gaya hidup, kepribadian, dan konsep diri. Faktor psikologis yang memengaruhi pilihan pembelian seseorang yaitu motivasi, persepsi, pembelajaran, serta keyakinan dan nilai.

Senada dengan penelitian yang dilakukan oleh Kotler \& Ketler, Radulescu \& Cetina (2012) menemukan bahwa terdapat dua faktor yang dapat memengaruhi konsumen dalam melakukan pembelian yaitu nilai yang ditawarkan oleh perusahaan dan nilai konsumen terhadap produk yang ditawarkan. Penelitian ini juga menunjukkan bahwa penjualan secara digital memberikan nilai kemudahan bagi konsumen.

Claudiu-catalin \& Dorian-Laurentiu (2014) menunjukkan bahwa terdapat dua faktor yang memengaruhi konsumen dalam membeli produk yaitu faktor intrinsik yang berasal dari diri sendiri dan juga faktor ekstrinsik yang berasal dari luar diri sendiri/lingkungan seperti rekomendasi dari teman. Hasil penelitian ini sesuai dengan dua jenis faktor yang di ungkapkan oleh Kotler \& Keller yaitu faktor sosial dan faktor kebudayaan termasuk dalam faktor ekstrinsik, faktor personal dan faktor psikologis termasuk dalam faktor intrinsik.

Analisis dari penelitian Cheng, Wang, \& Liu (2013) menunjukkan bahwa pada era $e$ commerce terdapat empat faktor yang memengaruhi perilaku konsumen dalam pembelian yaitu rational factors yaitu tingkah laku membeli karena nilai dari sebuah produk, emotional 


\section{Faktor-faktor yang Memengaruhi Perilaku Konsumen ....}

factors yaitu tingkah laku berbelanja karena ada emosi impulsif dan sering kali membeli barang yang kurang berguna, balanced factors yaitu tingkah laku berbelanja karena barang yang dijual sesuai dengan selera dan dengan harga yang murah, and hesitant factors yaitu tingkah laku ragu-ragu dalam berbelanja karena banyaknya informasi yang didapatkan di internet.

Gorkan, Furnham, \& Fagan (2014) menunjukkan bahwa strategi harga memengaruhi pembelian customer, tetapi harga yang murah belum tentu dibeli oleh customer karena tergantung dari brand yang ditawarkan. Jain \& Schultz (2016) menunjukkan bahwa referensi memengaruhi konsumen dalam perilaku pembelian dan pemilihan merek barang (brand). Cosma, Bota, \& Tutunea (2013) menunjukkan bahwa dalam memilih produk, customer memperhatikan penawaran melalui daring (online) terlebih dahulu. Labrecque, Esche, Mathwick, Novak, \& Hofacker (2013) menunjukkan bahwa social media platform memberikan kemudahan konsumen dalam membeli. Hal ini berpengaruh pada daya tarik, efektivitas, dan kemampuan untuk menggunakan yang dapat membuat konsumen merasa berguna.

Kervenoael, Aykac, \& Palmer (2009) menunjukkan bahwa perilaku implusif disebabkan tiga faktor. Pertama yaitu faktor fungsional seperti kenyamanan, informasi yang memadai, dan proses pembayaran, penjual yang interaktif, proses cepat. Kedua adalah faktor psikologis seperti keamanan bertransaksi, jaminan barang diganti jika salah/rusak. Ketiga adalah faktor konten seperti design produk, harga, dan promosi.

Parise, Guinan, \& Kafka (2016) menunjukkan bahwa penjual harus mampu menjelaskan produk yang ditawarkannya dengan baik dan interaktif, untuk dapat membuat konsumen merasa tidak terpaksa, "nyambung" dengan yang ditawarkan penjual dan merasa sesuai dengan yang dibutuhkan secara kognitif dan emosional. Dengan begitu membuat konsumen dapat merasa puas, mau mendengarkan penjelasan produk, mengingat produk yang ditawarkan, terlibat dalam produk yang ditawarkan, dan melakukan pembelian.

Berdasarkan penjabaran di atas, maka tujuan dari penelitian ini yaitu ingin mengetahui lebih dalam mengenai gambaran faktor-faktor yang memengaruhi transaksi konsumen di media sosial.

\section{Metode}

Metode penelitian dalam penelitian ini adalah metode penelitian kualitatif. Menurut Poerwandari (2013) penelitian kualitatif menghasilkan dan mengolah data yang sifatnya 


\section{Irfan Aulia Syaiful, Anggit Verdaningrum Kumala Sari}

deskriptif, seperti transkrip wawancara, catatan lapangan, gambar, foto, rekaman video dan lain sebagainya. Sesuai dengan paradigma penelitian, pendekatan kualitatif mencoba menerjemahkan pandangan-pandangan dasar interpretatif dan fenomenologis pada subyek dan gejala tertentu.

Pada penelitian kualitatif pengambilan subyek sebagai sumber data dilakukan berdasarkan kriteria tertentu. Adapun pertimbangan responden dalam penelitian adalah: 1). Laki-laki atau perempuan dengan durasi bermain media sosial di atas 2 jam sehari. 2). Melakukan transaksi di media sosial lebih dari satu kali. 3). Berusia 15 - 40 tahun. 4). Menggunakan akun media sosial lebih dari satu buah.

Adapun teknik pengumpulan data dalam penelitian ini adalah dengan wawancara. Wawancara dilakukan secara langsung antara peneliti dengan masing-masing subjek. Menurut Esterberg dalam Sugiyono (2010) wawancara merupakan pertemuan dua orang untuk bertukar informasi dan ide melalui tanya jawab, sehingga dapat dikonstruksikan makna dalam suatu topik tertentu.

Teknik analisis dalam penelitian ini merupakan jenis analisis ilustratif. Pada analisis ilustratif terdapat tiga metode yaitu case clarification, parallel demonstration, dan pattern matching (Neuman, 2014). Dalam penelitian ini analisis yang dilakukan lebih banyak mengacu pada analisis pattern matching. Pattern matching melakukan observasi dan hasil wawancara dengan pola yang ada di dalam teori tertentu atau hasil penelitian sebelumnya.

Teknik untuk melakukan analisis dilakukan dalam proses seperti berikut. Data yang terkumpul dari hasil wawancara dilakukan proses verbatim. Data ini kemudian dilakukan proses kodifikasi baik dalam bentuk kategorisasi terbuka. Data yang sudah dikategorisasi lalu disesuaikan dengan kategorisasi yang ada di dalam teori dan penelitian sebelumnya. Data yang sudah dikategorisasi kemudian dilakukan interpretasi dan elaborasi untuk mendapatkan gambaran mengenai fenomena tingkah laku transaksi konsumen di media sosial.

\section{Hasil}

\section{Gambaran Umum Subjek}

Secara umum, subjek dalam penelitian ini berusia antara 18 tahun hingga 33 tahun. Subjek terdiri dari lima orang dengan empat orang laki-laki dan satu orang perempuan. Keseluruhan subjek sudah bekerja, dengan latar belakang hobi yang berbeda-beda seperti 


\section{Faktor-faktor yang Memengaruhi Perilaku Konsumen ....}

bermain komputer, bermain bola, bermain futsal, bermain permainan daring, bermain voli, masak dan otomotif.

\section{Faktor Budaya}

Faktor Budaya sebagai latar belakang lingkungan konsumen dan/atau penjual dalam proses perilaku transaksi di media sosial digambarkan sebagai perilaku interaksi informal dengan ciri simbolik kata-kata sapaan yang khas sesuai dengan media sosial yang dipakai.

"Enggak sih, rata-rata semua yang gua temuin kaya seller seller gitu mereka sama aja sih, ga ada yang beda gua rasa, misalkan kaya gua pernah mesen barang, atau misalkan gua bilang Selamat Malam, Gan, Mereka balesnya juga sama sih, diantara seller seller yang lainnya" (Subjek AI)

Kata-kata yang sering dipakai sebagai sapaan dalam perilaku transaksi media sosial adalah sapaan yang khas seperti kata kata "selamat malam gan", "maaf nubi mau tanya". Ciri khas ini untuk menimbulkan kondisi emosi yang nyaman untuk bertransaksi antara penjual dan pembeli.

Hal ini dikarenakan bahasa merupakan salah satu faktor budaya yang mempunyai pengaruh signifikan dalam perilaku transaksi melalui media sosial.

"Dari bahasa kali yah, oh dari bahasa, pokoknya bahasa sangat berpengaruh walaupun di Sosial Media yah" (Subjek ER)

Kondisi yang nyaman ini disebutkan secara khas dengan istilah mencoba untuk "sok asik" antara penjual dan pembeli.

"Sebenernya sih untuk cara-cara kaya begitu, cara pandang budaya untuk misalkan kaya pembelian di sosial media online sih yah paling, kita Cuman kaya belaga sok asik aja ke orang yang penjual, dan begitu juga penjual ke pembeli yah, mereka juga akan sok asik juga ke kita, sama-sama kenal, ya kaya gitu aja sih, ibarat kata Sorry gan, Gua mau pesen nih, gitu, Malam gan, saya minat dong barang ini, gitu gitu, kaya gitu sih" (Subjek AI)

Untuk dapat merangkul konsumen agar bertransaksi, penjual juga menyebut istilah "lapak" sebagai istilah untuk akun media sosial tempat berjualan dan bertransaksi. Istilah ini bisa menyesuaikan dengan lokasi tempat tinggal penjual dan konsumen, sebagai contoh jika tempat tinggal penjual dan konsumen berada di kelompok etnis Jawa, maka bahasa dan istilah menyesuaikan dengan bahasa Jawa.

"Hmmm..., bisa jadi iya, karena seperti tadi bisa merangkul customernya, juga, mungkin dia ada di kelompok orang Jawa kan jadi Bahasanya Jawa, jadi lebih dekat, serasa lebih satu mengeras gitulah (Subjek tertawa) jadi bisa lebih akrab dalam berbincang, saling mengerti gitu kebiasaanya dan bisa jadi memengaruhi keputusan dia untuk bertransaksi dengan orang tersebut" (Subjek FM) 


\section{Irfan Aulia Syaiful, Anggit Verdaningrum Kumala Sari}

Hal ini dilakukan oleh penjual dalam rangka membangun keterhubungan, kenyamanan, dan ketertarikan yang memengaruhi sikap dan perilaku konsumen untuk dapat bertransaksi melalui akun media sosial penjual. Hubungan ini bersifat dua arah, artinya tidak hanya penjual menyesuaikan dengan pembeli, namun pembeli pun dapat secara aktif menyesuaikan dengan penjual.

"Bisa sebaliknya sih, seller (dalam hal ini yang dimaksud seller adalah pembeli) yang beradaptasi dengan penjual gitu kan, karena dia untuk merangkul para pembelinya itu, customernya. " (Subjek FM)

"Betul, selain itu kan sellernya itu mempunyai sebuah kebutuhan yang ada di sellernya, jadi sama-sama beradaptasi sih." (Subjek FM)

Dalam perilaku transaksi di media sosial konteks budaya terlihat cukup penting, hal ini diperlihatkan dengan beberapa pernyataan yang dilontarkan Subjek FM, Subjek MG, dan Subjek ER.

"Kemungkinan budaya luar, budaya Indonesia beradaptasi dengan budaya luar itu kecil yah, karena sekarang aja banyak orang bule belajar bahasa Indonesia gitu kan dan meneliti budayabudaya Indonesia gitu, jadi kemungkinan malah orang luar negerinya yang bakal belajar budaya Indonesia dulu untuk bertransaksi di sini. " (Subjek FM)

"Mungkin karena saya sendiri juga ga kenal dengan budaya lain seperti apa, jadi saya pandangnya sih sama sih, tapi yang jelas kalau di luar beda yah, karena Jakarta dan yang Lainlainnya udah termasuk Jawa, jadi sama. " (Subjek MG)

"Ya itu dia, kalau saya kan selama ini banyak tinggal di Jawa, jadi, jadi yaa...., sama aja, tapi kalau kita keluar misalnya disana atau berinteraksi dengan orang timur lewat Social Media, pasti kita tetep harus sopan lah, satu itu sopan, jadi kita juga harus liat budaya dia atau sifat dia, jadi yah pertama sih, untuk, untuk berinteraksi dengan budaya lain atau orang yang kita belum kenal, mungkin pertama harus sopan." (Subjek MG)

“Eh, berpengaruh kali yah," (Subjek ER)

"Kalau saya sih, misalkan orangnya penjual mana gitu, menyesuaikan gitu, sifat daerah itu kaya gimana jadi ga kaya, sopan lah, tergantung kita sih, jika kita sopan ke orang lain maka orang itu akan sopan kepada kita" (Subjek FN)

Berdasarkan hasil wawancara dengan kelima subjek tergambarkan faktor budaya sebagai faktor yang memengaruhi transaksi konsumen di media sosial seperti kalimat sapaan, penggunaan istilah, penyesuaian bahasa. Hal ini disebabkan pentingnya menjaga rasa nyaman dan kesopanan dalam bertransaksi di media sosial.

Dalam media sosial, baik penjual ataupun pembeli sama-sama melakukan penyesuaian. Penyesuaian yang dilakukan oleh penjual bisa sebagai cara untuk merangkul konsumen agar konsumen merasa nyaman dan tidak ragu bertanya mengenai produk yang 


\section{Faktor-faktor yang Memengaruhi Perilaku Konsumen ....}

di inginkan. Hal ini sesuai dengan penelitian sebelumnya yaitu penelitian Yakub, et al ., (2011) bahwa dalam membeli barang, kualitas dan pelayanan, budaya, keyakinan pelanggan dan tradisi memberikan pengaruh yang besar yaitu 86,8\%. Radulescu \& Cetina (2012) menunjukkan bahwa nilai yang ditawarkan oleh perusahaan memengaruhi customer dalam melakukan pembelian. Claudiu-catalin \& Dorian-Laurentiu (2014) menunjukkan bahwa faktor ekstrinsik memengaruhi customer dalam membeli produk. Hasil wawancara dengan kelima subjek yang bertransaksi dengan media sosial ini menguatkan gambaran faktor budaya sebagai faktor yang punya pengaruh dalam perilaku transaksi pembeli. Hal yang baru dalam penelitian ini adalah perilaku budaya tidak hanya tergambarkan punya peran dalam media konvensional tapi juga di media sosial di internet.

\section{Faktor Sosial}

Dalam transaksi di media sosial, faktor sosial memengaruhi perilaku konsumen seperti dengan adanya testimoni dan ulasan produk di media sosial seperti youtube, kaskus, dan diskusi grup di whatsapp.

"Itu hasil dari diskusi kelompok, kadang bisa memengaruhi juga yah, soalnya itu terjadi karena berbagai macam pengalaman kan, memang banyak berbagai sudut pandang tapi, kita ambil yang paling rata-rata terbesarnya, jangan sampai kita terjadi seperti itu lagi, mungkin memang bisa mengambil keputusan dari forum tersebut, sebagai bahan pertimbangan saja, begitu" (Subjek FM)

Ulasan ini meliputi kualitas foto produk, penjelasan bentuk dan jenis barang, pengalaman dalam pengiriman barang, dan pengalaman saat menggunakan produk. Hal ini terlihat dan digambarkan dari hasil wawancara dengan Subjek FM, Subjek MG, Subjek ER, dan Subjek AI.

"Pastinya kelebihan barang itu kalau berjualan yah, barangnya mungkin punya fitur apa gitu kan, terus yah bersaing gitu dan yang lainnya biar menarik pembelinya gitu. Discountdiscount tertentu, pelayanannya bagus, gitu-gitu lah. " (Subjek FM)

"Betul! Jadi disetel-setel gitu kan tulisannya atau ditaruh foto-fotonya yang bagus jangan burem, bersih gitu"( Subjek FM)

"Oh iya, story telling dari dagangan dia, itu penting itu!" (Subjek MG)

"Mungkin kalau barang yang kita pengen gua incer itu pertama dari gambar dia yang foto yah, maksudnya fotonya yang jelas, detail, dan benar-benar semua barang dari yang dibeli itu difoto sama dia, apa isi dari barang itu difoto dia, tapi kalau misalnya gua ga laper mata atau misalnya gua ga lagi cari barang atau tapi kelihatan menarik itu mungkin yang dari keunikan sih dari barang tersebut, itu sih yang pertama yang bisa bikin gua tertarik membeli barang tersebut, udah yah" (Subjek MG) 


\section{Irfan Aulia Syaiful, Anggit Verdaningrum Kumala Sari}

"Dari barang lain, Warna, atau ya itu background foto dia atau bikin, menarik atau apa yah? Selera yah kalau unik itu kan selera yah? Saya juga ga bisa ngejelasin, yang denger juga jadi bingung maksudnya gimana, itu sih yang pen, yang penting unik aja." (Subjek MG)

"(Subjek masih tertawa) Iklan baris, terus yang jadi disini kan udah kita dikasih media gratis, harusnya kan lebih komplit dari pos kota dan yang lain-lain, yang lain kan bayar, saya ga suka kalau yang ngasih terlalu singkat gitu, jadi kita kan tanya lagi ke sellernya dan kadang-kadang sellernya juga kesel kan, harusnya sih sellernya itu lebih pintar lah." (Subjek MG)

"Ia mencari informasi dulu, browsing-browsing dulu terus kalau udah cocok sama harga sama barang yang dinginkan terus kita biasanya sih kalau dulu di Wonogiri itu ketemuan langsung, jadi penjual kan yang jual di forum kalau di Wonogiri, jadi kita langsung ketemuan langsung lihat barangnya terus kita bayarnya juga langsung," (Subjek FN)

"Aku yah, kalau aku sih sebenernya, apa sih, hm, kalau beli di online juga aku pertama kenal dulu tuh sama orangnya, kebeneran, kebetulan itu tuh yang punya barangnya temen sendiri, jadi aku ga perlu was was, ini itu ga yah, nyampe ga yah, pertama itu, udah aku udah diskusi sama temen, eh kalau kekecilan bisa dituker kann? Oh yah, bisa, dah kalau pas udah udah barangnya ini baru dah aku transfer, karena aku kenal dia kali, yah awalnya sih itu." (Subjek ER)

"Misalkan kaya, ibaratkan gua mau cari barang-barang motor gitu, gua males mau pergi gitu, gua searching-searching dong, yang jual barang, sesuai speks speks yang gua mau, yang sesuai apa keinginan gua, setelah gua cari cari, gua dapat tuh tokonya tuh, akhirnya gua langsung dateng ke tempat itu karena masih berdekatan, kaya misalkan gua di Pluit dia di Depok itu kan pasti bisa tuh gua samperin ke sana, dari situ akhirnya gua bisa liat ada barang-barang lain yang sesuai sama seperti yang gua harepin, nah dari situ gua akhirnya gua bisa kenal sama yang punya bengkel, kenal sama anak yang beli di situ, jadi gua tuh menjembatani untuk mempermudah mendapatkan apa yang gua mau," (Subjek AI)

"Karena kalau kita nongkrong di bengkel tuh orangnya pasti ngomong kalau punya barang baru, gua pake ini enak Bi, tanya aja Yuda, Yuda tuh mekanik gua, Yuda bilang enak kok knalpotnya, jadi yah gua beli, walaupun menurut gua itu kurang enak, kita jadi terpengaruh gitu," (Subjek AI)

Hasil ulasan ini menjadi lebih penting ketika pengulas mempunyai kesamaan profil dengan pembeli.

"Saya sih banyaknya grupnya di Whatsapp, kalau misalkan di kaskus yah lihat review-review orang aja atau di youtube, youtuber Indonesia kan dah banyak tuh, merajalela jadi bisa langsung liat videonya langsung, kalau mau beli barang unboxingnya, reviewnya, atau apanya gitu. " (Subjek FM)

Berdasarkan hasil wawancara menggambarkan bahwa faktor sosial mempunyai peran yang signifikan dalam perilaku transaksi konsumen di media sosial. Ulasan dari teman yang dipercaya seperti dikatakan Subjek ER menjadi alat yang memengaruhi keputasan membeli dan perilaku transaksi.

"Iya, tertarik yah, aku pernah tuh, temenku nawarin apa yah," Subjek ER) 


\section{Faktor-faktor yang Memengaruhi Perilaku Konsumen ....}

"Apa yah, jadi temenku pernah ngirim gambar tuh sepatu, yah harganya sih lumayan lah, terus ini lagi discount loh, harganya murah, bagus, gini gini, 1 ngomong, ah udah yah gua pesen satu, ya udah jadi dari beberapa itu ada lah, orang yang mau itu juga, yang mau." (Subjek ER)

Faktor sosial ini muncul dan mempunyai peran memengaruhi pada perilaku transaksi di media sosial pada berbagai bentuk dan saluran. Sebagai contoh bentuk dan saluran tersebut adalah melalui (1) diskusi seperti yang terjadi pada media sosial whatsapp, (2) ulasan video tentang produk di youtube dan (3) cerita dan pernyataan pengalaman penggunaan produk pada forum jual beli kaskus, dan (4) ulasan foto yang diambil dan berbagai sisi seperti yang ada pada media sosial instagram. Empat bentuk ini menjadi faktor sosial yang terlihat dominan pada perilaku transaksi konsumen di media sosial. Hal ini sesuai dengan beberapa penelitian sebelumnya yang memperkuat faktor sosial memengaruhi perilaku transaksi. Claudiu-Catalin \& Dorian-Laurentiu (2014) menyebutkan bahwa faktor ekstrinsik yang berasal dari luar diri sendiri/lingkungan seperti rekomendasi dari teman memengaruhi customer dalam membeli produk. Jain \& Schultz (2016) menunjukkan bahwa refrensi memengaruhi customer dalam perilaku pembelian dan pemilihan brand.

Labrecque, Esche, Mathwick, Novak, \& Hofacker (2013) menunjukkan bahwa social media platform memberikan kemudahan konsumen dalam membeli, namun hal ini juga mendorong konsumen ragu-ragu dalam berbelanja karena banyaknya informasi yang didapatkan di internet (Cheng, Wang, \& Liu, 2013). Hal ini dikategorikan sebagai faktor sosial dalam perilaku transaksi konsumen di media sosial.

\section{Faktor Personal}

Dalam transaksi di media sosial, faktor personal memengaruhi perilaku konsumen. Faktor personal ini muncul dari interaksi konsumen selama menggunakan media sosial. Dari hasil wawancara faktor personal ini terlihat dari motivasi membeli, kecenderungan impulsif untuk membeli barang, kesenangan yang didapatkan dari berbelanja, dan kemudahan yang didapatkan pada proses pembelian barang.

Hal yang menarik dari faktor personal adalah adanya pengakuan dari subjek yang merasa membeli barang dengan impulsif dan terburu-buru.

"Selalu mikir $2 x$ atau lebih sih, kenapa harus beli barang yang dibutuhin, sering sih sering, masih sering malahan kenapa, kadang-kadang nyesel juga, kenapa gua beli ini yah, kenapa gua beli itu, akhirnya yah gua jual lagi lah mungin kalau pengen untuk ehmmm mempuaskan hasrat ya ga papa beli, harga jualnya jatoh, tapi kalau untuk barang yang murah-murah ya itu sih jadi sampah malahan." (Subjek MG) 


\section{Irfan Aulia Syaiful, Anggit Verdaningrum Kumala Sari}

"Iyaaaa, karena butuh, kedua tetep sih harga murah daripada yang lain walau ga butuh-butuh amat, karena mungkin ke depannya nanti yah itu, pengen hasrat tadi, ngepuasin hasrat, kalaupun ga butuh-butuh banget jadi kalau harga miring yah Tarik aja, dibeli aja, entah itu dipake atau enggak kan urusan belakang aja yang penting harga murah dulu." (MG)

Dengan adanya media sosial, subjek merasa membeli produk yang sebetulnya tidak dibutuhkannya. Kecenderungan ini dirasakan karena media sosial memberikan saluran langsung bagi konsumen untuk berinteraksi secara personal dengan produk tanpa dibatasi waktu dan ruang.

"Jadi bermalas-malasan yah, (Subjek tertawa) misalkan pulang kerja terus butuh apa gitu kan, tinggal liat HP atau tinggal liat laptop bisa liat barang-barang yang ini berapa sih, berapa sih. Tapi kalau emang urgent banget mending langsung ke tokonya yang terdekat gitu." (Subjek FM)

"(Menjawab sambil tertawa) Sedang sikon sudah cape tapi masih dapat berbelanja." (Subjek $\mathrm{FM})$

"Yaaaa, gimana yah, pokoknya kalau social media yah mudah banget, hmm, terus kita ga capekcapek ke toko, ke mana gitu." (Subjek FN)

"Jelaskan, Hm..., ya kalau lewat social media kan mudah, gampang, jadi tinggal ngomong bentar barang udah dateng, kalau langsung kan kita pergi dulu ke toko, kemana, nyari dulu gitu, kalo di social media kan tinggal milih." (Subjek FN)

"Mempermudah banget emang," (Subjek AI)

"Iya, waktu, karena social media kita sambil mandi, kita juga bisa pesen barang, ya gitu kan." (Subjek AI)

"He eh, kita tinggal searching apa yang kita mau, nongol di situ, hampir semua." (Subjek AI)

"Ada beberapa yang, kenapa gua lebih tertarik yah beli di Online yah, Khususnya, Ehm. . , pertama karena waktu, karena jarak juga, waktu, jarak sama keterbatasan ketersediaan di toko offline atau di toko fisiknya, itu yang menurut gua tertarik beli di toko online." (Subjek MG)

"Kan Social Media itu mudah, tinggal duduk nyari barangnya tinggal ngetik sih udah nongol sendiri." ( Subjek FN)

Dari hasil wawancara konsumen merasa kemudahan ini seperti pisau bermata dua, di satu sisi memberikan kemudahan untuk mendapatkan barang yang diinginkan, di sisi lain menyulitkan untuk menahan diri hanya membeli barang yang dibutuhkan. Walaupun subjek mampu membedakan mana kebutuhan dan keinginan tetapi terkadang subjek tetap membeli produk yang kurang dibutuhkan bila harganya murah dan menarik.

"Hmm..., intinya sih kalo beradaptasi ngeliat, dari kebutuhan aja sih bisa ngebedain antara kebutuhan sama keinginan, gitu kan. Kalau emang itu perlu dan butuh yah diambil kalau misalkan itu hanya keinginan itu dijadikan prioritas keberapa gitu kan, tetep harus memanfaatkannya dengan baik tentang medsos tersebut." (Subjek FM) 


\section{Faktor-faktor yang Memengaruhi Perilaku Konsumen ....}

“(Subjek tertawa) masih bisa ketahan sih masih bisa ketahan, soalnya banyak keperluan, lagian kan kuliah sambil kerja juga gitu kan harus bisa nahan hemat-hematnya gitu. Jadi kalau emang kepengen pas lagi ada duitnya aja." (Subjek FM)

"Menggampangkan lah" (Subjek FM)

"Sama satu lagi biasa harga lebih murah! Kalau di online itu, karena mungkin mereka belinya stocknya dari distributor lain atau gimana, gitu kenapa gua lebih tertarik beli di toko online. Berapa kalinya dalam setahun atau sebulan ga keitung yah, saya beli sih barang sih tergantung kebutuhan sih, jadi selama saya butuh ini ya cari online dulu, pertama online. Kalau ga ada ya offline." (Subjek MG)

"Ya kalau pengalaman sih pernah sih kaya gitu, kaya kan saya sudah punya sepatu voli, udah liat ada yang lebih bagus lagi nih, padahal kan ga butuh, udah punya, tinggal beli, berapa, lumayan sih, lumayan ya..." (Subjek FN)

“Gimana yah, gua juga susah sih untuk ngomongnya, emang dari dalam diri gua sendiri sih, gua tipe orang yang udah kalau pengen ya gua harus dapetin itu barang, jadi kalau gua misalkan mau ini, terus ada lagi iklan baru yang gua pengen gua tetep ga akan terpengaruh sama barang itu, gitu sih gua, gua tipe orang yang kalau udah pengen harus, jadi gua ga bisa belok belok buat dapet barang lain, sesuai apa yang gua mau." (Subjek AI)

"He eh, sizenya udah aja, contoh kalo XL gede yah udah itu, tapi ya itu ga ada yang buat lebih gedenya lagi, kalau misalnya di Online tuh, yah gitu juga sih, terus karena praktis kali yah," (Subjek ER)

"Iyah, Iya, bener, jadi kalau misalnya, kalau kita nyari ke toko kan, aduh berlama-lama, kalau online kan cukup nyari, oh ini cocok ya udah ini aja gitu." (Subjek ER)

“Gimana yah? Susah yah, kalau kita misalnya juga mau ke mall nanti mau belinya ini, tautaunya melencong ke sini, jadi siasatinya gimana ya, jadi kalau setiap kalau misalnya kita sebelum berangkat jadi dicatetin dulu tuh, apaan aja yang harus dibel.i" (Subjek ER)

Berdasarkan hasil wawancara tergambarkan bahwa faktor personal memengaruhi transaksi konsumen di media sosial. Faktor personal yang muncul dalam perilaku transaksi konsumen di media sosial meliputi (1) kemampuan mengelola dorongan impulsif saat membeli barang, (2) pengalaman personal dengan proses pemilihan dan pembelian barang, (3) gaya berbelanja dan cara membelanjakan uang, dan (4) kesadaran akan kesesuaian antara kebutuhan dan keinginan membeli barang.

Faktor Psikologis

Dalam transaksi di media sosial, berdasarkan hasil wawancara faktor psikologis yang menjadi motivasi konsumen untuk bertransaksi di media sosial adalah harga produk yang ditawarkan kepada konsumen. Harga yang dimaksud dalam hal ini adalah pemberian 


\section{Irfan Aulia Syaiful, Anggit Verdaningrum Kumala Sari}

diskon, pemberian produk tambahan. Di dalam benak konsumen terlihat bahwa transaksi di media sosial dapat memberikan kesempatan bagi konsumen untuk mendapatkan harga yang lebih murah dibandingkan melalui pasar konvensional.

“Discount!" (Subjek FM)

“Apa lagi yah? Aaa. . ", kaya ya balik lagi ke harganya bersaing yah, terus spesifikasinya juga lengkap, reviewnya juga lengkap, gitu." (Subjek FM)

"Yang pasti, yang gua pengen pasti ada discount yah, pertama harga miring dari seller lain," (Subjek MG)

"Iyah, apalagi misalnya gratis ongkos kirim." (Subjek ER)

"Harganya juga, jangan mahal banget." (Subjek ER)

"Iyah, discountnya juga." (Subjek ER)

Yang kedua mempunyai pengaruh adalah persepsi konsumen mengenai reputasi dari penjual. Reputasi ini meliputi kemampuan menangani keluhan, ketetapan janji, dan kemampuan untuk mengemas barang sehingga tampil menarik bagi pembeli.

"Hm..., balik lagi kaya tadi, Aaaa..., cepat layananya, ada kepastian setelah membeli barangnya tidak menghilang begitu saja dan terpercaya dalam transaksi." (Subjek FM)

"Atau ini yang, yang mungkin tempat lain diremehkan, ini sangat penting buat gua nih, ehmm, Packaging, saat dikirim, gua paling suka sama seller yang packagingya rapi dikasih bubble dikasih ehm, bungkus kardus yang karton yang coklat, walopun terlihat sepele namun itu melindungi barang yang lu beli, itu sangat penting banget walopun harga sama tapi saat packagingnya beda kan itu kan bahaya kan." (Subjek MG)

"Iya, complain dulu terus tanggapan dia kaya gimana, apa bisa ditukar dengan yang lain atau tidak ada stock yang lain atau gimana, kembalikan uangnya atau gimana gitu." (Subjek FM)

“Oh, iya yah, pertama kali melihat gua menarik atau membeli barang dia itu." (Subjek MG)

"Tapi real juga, kan dari gambarnya sama kita pesen sama asli, iya juga harus real." (Subjek ER)

\section{"Sebenernya eye catching" (Subjek AI)}

"Kita, kalau misalnya kita beli lewat Whatsapp, gitu kan hubungin dia langsung lewat bbm, paling kita komplain kaya gitu, kadang sih mereka suka ada yang ga bertanggung jawab sih, langsung noilang atau kita di delete atau kita ga di bales, kita telfon ga diangkat, itu sih yang jengkelin cuman yah, itu lah resiko kalau beli di online shop atau sosmed sih, itu kan resikonya, jadi apa yang kita keluarkan untuk membeli barang di sosial media kita harus punya sifat, gimana yah?" (Subjek AI)

"Aware, nah gitu, iya hati-hati, nah jika emang ternyata barang yang nyampe ga sesuai sama yang diinginkan nah itu resikonya karena kita beli di dunia online, kita ga bisa komplain langsung datang ke tokonya gitu, kita ga tau rumahnya dimana." (Subjek AI) 


\section{Faktor-faktor yang Memengaruhi Perilaku Konsumen ....}

"Iya, bener banget, makanya pilih pilih banget gua kalau beli di online shop, mendingan gua cari alamatya dimana, kalau bisa gua samperin, gua sanggup gua samperin, gitu." (Subjek AI)

"Yang diharapin? Yang diharapin yah barang barang yang diiklanin itu yah sama dengan yang dikirim, yang diharapan gitu sih, enggak, barang yang diiklanin itu ori eh dikirim KW." (Subjek FN)

"Oh, orangnya jujur yah, terus kalau misalnya harus tepat waktu misalnya, ditanya berapa hari nih nyampenya, 2 hari yah 2 hari jangan lebih." (Subjek ER)

"He eh, dan bisa di komplain." (Subjek ER)

"Kalau ditanggepin, oh iya yah terima kasih yah, berarti, jadi kalau seandainya ada barang yang bagus kita bisa ke situ lagi," (Subjek ER)

"Udah sih gitu aja, yang penting jujur, terus komitmen bisa dipercaya, bisa dipercaya maksudnya dia jual beneran jual ga cuma boongan, suka jual apa ternyata nggak, hmm, gitu." (Subjek FN)

"Nyari seller lain iya." (Subjek FN)

"Oh, orangnya jujur yah, terus kalau misalnya harus tepat waktu misalnya, ditanya berapa hari nih nyampenya, 2 hari yah 2 hari jangan lebih." (Subjek ER)

"He eh, jadi kalau sekali kita udah dikeceawain yah udah berarti kita ga usah disitu lagi." (Subjek ER)

Berdasarkan hasil wawancara menggambarkan bahwa faktor psikologis memengaruhi transaksi konsumen di media sosial. Faktor psikologi yang muncul tergambarkan dari (1) persepsi mengenai harga (seperti discount, gratis ongkos kirim, dan hadiah), (2) motivasi untuk membeli dan (3) persepsi mengenai reputasi dari penjual yang terdiri dari packaging produk yang rapi dan eye catching, produk yang didapatkan sesuai dengan gambar produk yang ada di media sosial, kepastian dan kemudahan pengiriman barang kepada pembeli, kepastian produk penjual, dan kemampuan melayani keluhan dengan baik.

Ketiga hal ini membentuk kepercayaan konsumen kepada penjual. Hal ini sesuai dengan penelitian sebelumnya yang dilakukan oleh Hajli (2013), mengungkapkan kepercayaan konsumen memiliki pengaruh signifikan terhadap pada niat untuk membeli konsumen. Wang, \& Liu (2013) bahwa pada era e-commerce yang memengaruhi perilaku pembelian adalah balanced factors yaitu customer berbelanja karena barang yang dijual sesuai dengan selera customer dan harga yang murah. Hasil penelitian juga sejalan dengan studi yang dilakukan Kervenoael, Aykac, \& Palmer (2009) mengenai faktor fungsional, psikologis dan konten.

Hasil penelitian juga sesuai dengan penelitian Gorkan, Furnham, \& Fagan (2014) menunjukkan bahwa strategi harga memengaruhi pembelian. Hasil penelitian juga sesuai 


\section{Irfan Aulia Syaiful, Anggit Verdaningrum Kumala Sari}

dengan penelitian yang dilakukan oleh Parise, Guinan, \& Kafka (2016) bahwa pembeli akan membeli dari penjual yang dipercaya.

\section{Simpulan}

Berdasarkan hasil penelitian didapatkan kesimpulan bahwa subjek secara umum, faktor budaya digambarkan mampu menjadi faktor yang mempunyai peran memengaruhi transaksi konsumen di media sosial. Hal ini tergambarkan dalam interaksi antara penjual dan pembeliseperti penggunaan kalimat sapaan dan pemakaian istilah antara konsumen dengan penjual.

Dari hasil penelitian faktor budaya memberikan peran dalam proses transaksi diantara penjual dan konsumen. Penjual dan konsumen akan saling beradaptasi, sehingga tercipta satu kondisi nyaman yang diberikan istilah "sok asik" antara penjual dan konsumen. Sebagai contoh kondisi "sok asik" antara penjual dan pembeli adalah penggunaan kalimat sapaan "selamat malam gan". Faktor budaya juga dijadikan salah satu cara untuk merangkul konsumen, agar konsumen lebih nyaman dalam bertanya-tanya mengenai produk yang diinginkannya.

Dari hasil penelitian faktor sosial memberikan peran dalam proses transaksi konsumen di media sosial lewat ulasan dan masukan yang disampaikan mengenai produk. Hal ini tergambarkan lewat proses rekomendasi dari orang lain seperti testimoni-testimoni dan ulasan produk yang beredar di media sosial dalam berbagai bentuk. Adapun bentuk saluran yang dipakai untuk menyebarkan informasi tersebut dapat dilihat dari group-group diskusi seperti di whatsapp, forum diskusi kaskus. Selain itu, ulasan penjual dalam mempromosikan produknya memberikan dampak penting bagi perilaku transaksi konsumen di media sosial seperti cara pengambilan foto produk, kualitas gambar produk yang bagus serta penjelasan mengenai produk yang detail. Selain itu, ulasan produk dari teman dan orang yang mempunyai profil sama dengan konsumen lebih mampu memengaruhi konsumen untuk membeli produk di media sosial.

Dari keseluruhan subjek secara umum, faktor personal memengaruhi transaksi konsumen di media sosial. Faktor personal yang muncul adalah kebutuhan konsumen yang terpuaskan dengan kemudahan membeli dan memilih produk, kemudahan untuk mendapatkan penanganan dari penjual saat menyampaikan keluhan, kepastian produk dan kecepatan pengiriman. Di dalam faktor personal konsumen belajar mengenai reputasi dari penjual. Reputasi penjual ini mempunyai peran yang besar bagi keputusan konsumen 


\section{Faktor-faktor yang Memengaruhi Perilaku Konsumen ....}

untuk melakukan transaksi di dalam media sosial. Reputasi ini terbentuk dari interaksi antara penjual dan pembeli di media sosial.

Faktor psikologis memengaruhi transaksi konsumen di media sosial melalui harga yang murah dibanding dengan penjual yang lain, adanya discount, penanganan complaint dari pembeli oleh penjual, pengemasan produk saat pengiriman, produk yang ditawarkan sesuai dengan produk yang diterima oleh konsumen, produk yang sesuai dengan yang dibutuhkan, gratis ongkos kirim, produk yang eye catching, dan adanya bonus produk tambahan.

Saran

Berdasarkan hasil pembahasan dan analisis, peneliti mengajukan saran sebagai berikut untuk perusahaan ataupun penjual yang melakukan penjualan melalui media sosial sebaiknya meningkatkan kenyamanan dan kepercayaan lebih kepada konsumen seperti keamanan dalam transaksi, melakukan packaging produk dengan baik. Penjual juga harus memperhatikan complaint dari pelanggan dengan baik. Penjual juga disarankan membuat bentuk penawaran produk yang mampu memberikan efek "wow" kepada konsumen dengan cara menambahkan diskon ataupun memberikan hadiah produk lain atas pembelanjaan yang dilakukan, dan adanya event gratis ongkos kirim.

\section{Daftar Pustaka}

Ahmetoglu, G., Furnham, A. , \& Fagan, P. (2014). Pricing practices: A critical review of their effects on consumer perceptions and behaviour. Journal of Retailing and Consumer Services, 21, 696-707.

Akhter, S. H. (2003). Digital divide and purchase intention: Why demographic psychology matters. Journal of Economic Psychology, 24, 321-327.

Budiman, A., Chhor, H., Razdan, R., \& Sohoni, A. (2012). The new Indonesia consumer. McKinseyECompany.

Chen, M., Wang, Q., \& Liu, H. (2013). Matching relationships between consumer psychology and digital goods rankings. LISS 2013: Proceedings of 3rd International Conference on Logistics, Informatics and Service Science.

Claudiu-Catalin, M. \& Dorian-Laurentiu, F. (2014). Radical brand extensions and consumer profile - a new perspective on innovation and consumer innovativeness. Procedia Social and Behavioral Sciences, 109, 108-112.

Cosma, S., Bota, M., \& Tutunea, M. (2012). Study about customer preferences in using online tourism Products. Procedia Economics and Finance, 3, 883-888. 


\section{Irfan Aulia Syaiful, Anggit Verdaningrum Kumala Sari}

Habibi, M. R., Laroche, M., \& Richard, M. O. (2016). Testing an extended model of consumer behavior in the context of social media-based brand communities. Computer in Human Behavior, 62, 292-302.

Hajli, M. N. \& Nick, M. (2013). A study of the impact of social media on consumers. International Journal of Market Research, 56 (3)

Ioanas, E. \& Stoice, I. (2014). Social media and its impact on consumers behavior. International Journal of Economic Practices and Theories, 4(2).

Jain, V. \& Schultz, D. E. (2016): How digital platforms influence luxury purchase behavior in India?, Journal of Marketing Communications, DOI: 10. 1080/13527266. 2016. 1197295

Kervenoael, R., Aykac D. S. O. , \& Palmer, M. (2009). Online social capital: Understanding eimpulse buying in practice. Journal of Retailing and Consumer Services, 320-328.

Kotler, P. \& Keller, K. L. (2008). Manajemen pemasaran, Jilid 1. Jakarta: Penerbit Erlangga.

Labrecque, L. I., Esche, J., Mathwick, C., Novak, T. P., \& Hofacker, C. F. (2013). Consumer power: Evolution in the Digital Age. Journal of Interactive Marketing, 27, 257-269.

Madni, R. G. (2014). Consumer's behavior and effectiveness of social media. Globar Journal of Management and Business Research: E Marketing,14(8).

Mukhaini, E., Ismael, S., \& Al-Dhuhli, I. (2014). The impact of using sosial media on consumer buying behavior. Special Topics in Information Systems.

Neuman, W. L. (2014). Social research methods: Qualitative and quantitative approaches. Seventh Edition. UK: Pearson

Parise, S., Guinan, P. J., \& Kafka, R. (2016). Solving the crisis of immediacy: How digital technology can transform the customer experience. Business Horizons (2016), DOI: http://dx. doi. org/10. 1016/j. bushor. 2016. 03. 004

Petra, M. (2012). Research of the behavior of consumers in the insurance market in the Czech Republic. Journal of Competitivenes, 4(2), 20-37.

Poerwandari, K. (2011). Pendekatan kualitatif untuk penelitian perilaku manusia, Edisi Ketiga. Depok: LPSP3 UI

Radulescu, V. \& Cetina, I. (2012). Customer analysis, defining component of marketing audit. Procedia - Social and Behavioral Sciences, 62, 308-312.

Sugiyono. (2010). Metode penelitian kuantitatifkualitatif dan RED. Bandung: Alfabeta.

Yakup, D., Mucahit, C., \& Reyhan, O. (2011). The impact of cultural factors on the consumer buying behaviors examined through an empirical study. International Journal of Business and Social Science, 2(5).

Zarrella, D. (2010). The social media marketing book. Jakarta: PT. Serambi Ilmu Semesta. 